specialists in the agro-industrial complex in the field of physical culture, sports, healthy lifestyle and professional-applied physical training.

Key words: professional-applied knowledge, physical education, level, component, volume of knowledge, students of agrarian specialties.

УДК 796.011.3(073):378.4

Роман Харченко

Сумський національний аграрний університет ORCID ID 0000-0002-7683-5835

Сергій Хоменко

Сумський національний аграрний університет ORCID ID 0000-0002-2105-0432

Андрій Красілов

Сумський державний педагогічний університет імені А. С. Макаренка ORCID ID 0000-0002-7725-5074

Петро Рибалко

Сумський державний педагогічний університет імені А. С. Макаренка ORCID ID 0000-0002-6460-4255

DOI 10.24139/2312-5993/2019.05/183-194

\title{
МЕТОДИКА ВИКЛАДАННЯ НАВЧАЛЬНОЇ ДИСЦИПЛІНИ «ФІЗИЧНЕ ВИХОВАННЯ» У ЗАКЛАДІ ВИЩОЇ ОСВІТИ
}

Зміст даної статті полягає у створенні і апробації методики, яка дозволяє враховувати особливості студентів у залежності від обсягу спеціальної рухової активності й успішності навчання, суттево підвищуючи продуктивність їх рухових умінь та пізнавальної активності. Розглянуто стан вищої освіти на сучасному етапі розвитку суспільства. По-перше, на фоні загальних змін, які відбуваються з вищою освітою, а, по-друге, з урахуванням особливостей програмного змісту навчання студентів закладу вищої освіти й контингенту студентів.

Ключові слова: студент, фрізичне виховання, навчання, заклад вищої освіти, здоров'я, фрізичні якості.

Постановка проблеми. Стрімкі зміни в умовах сучасного розвитку та Європейський вектор розвитку вимагають суттєвих змін у всіх сферах життя.

Ці зміни не оминули й освіту. Освітній процес у вищій школі пов'язаний із підвищеним інтелектуальним навантаженням і, як наслідок, із домінуванням діяльності центральної нервової системи (найчастіше підвищеної інтенсивності) над життєдіяльністю всіх інших базових систем організму студентської молоді (Закон України «Про фізичну культуру і спорт»). 
Пріоритетним напрямом державної політики є зміцнення здоров'я населення, особливо студентів, які навчаються в закладах вищої освіти. Основним засобом покращення здоров'я $€$ рухова активність, яка може реалізовуватись як в аудиторній, так і позааудиторній формах занять (Куртова та ін., 2018).

Але малорухливий спосіб життя та пов'язаний із ним дефіцит рухової активності, властивий як навчальній, так і будь-якій іншій інтелектуальній діяльності, негативно впливає на функціональні можливості скелетної мускулатури, знижує їі функціональні можливості, що відбивається на інтенсивності іннервації значного числа внутрішніх органів, діяльності серцево-судинної системи та протіканні метаболічних процесів, що вкрай згубно позначається на життєдіяльності організму (Рибалко, 2016). І саме в закладах вищої освіти (ЗВО) остаточно закріплюється домінування інтелектуальних і матеріальних індивідуальних потреб над фізичними, унаслідок чого гіподинамія стає атрибутом життя індивіда та звичним стереотипом поведінки, що неминуче призводить до виникнення й розвитку комплексу соматичних захворювань (Рибалко та ін., 2016).

Аналіз актуальних досліджень. Різні аспекти ставлення студентів до занять фізичними вправами вивчали багато вчених у галузі педагогіки, психології та фізичного виховання. Методологічні основи фізичного виховання розглядаються в роботах А. Дубогай, Т. Круцевич, О. Худолія, Б. Шияна. Розвиткові фізичних та психологічних якостей присвячені дослідження Е. Вільчковського, Л. Ковальчук, Н. Москаленко, К. Огнистої.

Однією з важливих складових системи освіти студентської молоді $\epsilon$ фізичне виховання, головною метою якої $є$ покращення рівня здоров'я, про що неодноразово у своїх роботах зазначали С. Гаркуша, М. Носко та інші.

Рядом фахівців пропонується розумно обмежити кількість видів спорту, що культивується у ЗВО з урахуванням інтересу студентів (Кисельов, та Маркіянов, 1999). Існує інша точка зору. Передбачається, що максимальне урізноманітнення навчального процесу нетрадиційними засобами й методами сприятиме зростанню мотивації до занять з ФВ (Боднар, 1998).

Дослідження фахівців у галузі фізичного виховання студентів (Ю. Козерук, Г. Куртова, П. Рибалко, С. Харченко) доводять, що сучасна молодь, на жаль, стає фізично слабшою, розвиток рухових якостей не відповідає вимогам сучасної професійної підготовки (Козерук та Новопашен, 2014; Куртова та ін., 2018; Рибалко та ін., 2016).

Вивченню особливостей рухової активності студентської молоді присвятили свою діяльність чимало науковців. Зокрема, Н. Земська 
визначила рівні рухової активності студентської молоді та оцінила структуру добової рухової активності студентів для вдосконалення системи фізичного виховання студентів (Козерук та Новопашен, 2014).

У процесі планування дисципліни «Фізичне виховання» в деяких закладах вищої освіти планують одну-дві академічні години на тиждень 3 метою економії, тим самим економлячи на здоров'ї студентів, що, на думку вчених, є неприпустимим (Куртова та ін., 2018; Рибалко та Хоменко, 2018).

Як зазначають (І. Самохвалова, В. Мелюшкина, П. Рибалко), настільний теніс, як складова частина програми з фізичного виховання, $\epsilon$ одним із засобів вирішення основних завдань фізичного розвитку студентської молоді, зміцнення здоров'я, формування й удосконалення рухових умінь і навичок, виховання основних фізичних якостей та психофізичних можливостей (Самохвалова та ін., 2018).

Мета статті - розширити знання студентів про особливості методики викладання дисципліни «Фізичне виховання» у ЗВО.

Завдання. 1. Поглибити знання студентів щодо психофізіологічних особливостей організму студентської молоді. 2. Озброїти знаннями 3 особливостей методики розвитку рухових якостей та навчання руховим діям студентів. 3. Сприяти формуванню наукового світогляду, моральних та етичних якостей студентського колективу.

Виклад основного матеріалу. Студенти, згідно з віковою періодизацію, належать до категорії «дорослого населення». Для осіб цієї категорії $\epsilon$ характерною низка психофізіологічних особливостей. Вік 18-29 років характеризується розквітом біологічної зрілості й надійністю функціонування всіх систем організму. До 18-20 років сповільнюється зростання тіла в довжину, остаточно формуються системи енергозабезпечення. Організм людини володіє найбільшою стабільністю, економічністю та реактивністю у відповідь на стрес-чинники будь-якої модальності. В осіб зберігається високий рівень здатності до тренувань, особливо сили й витривалості. Разом із тим, у віці 25-30 років, а іноді і раніше, у залежності від спадкових і середовищних чинників, починають розвиватися процеси інволюції рухової функції, які проявляються в уповільненні адаптації функціональних систем до умов зовнішнього середовища. Ці процеси протікають гетерохронно і, насамперед, торкаються нейромоторних механізмів. Інволюційні зміни призводять до зниження збудливості й рухливості нервових процесів, збільшенні фаз абсолютної і відносної рефрактерності, розвитку процесів пессимального гальмування при більш рідких, ніж у підлітків, подразненнях. 
Зменшується сила скорочень серцевих м'язів. Знижується еластичність судин. Стінки судин потовщуються, просвіт - зменшується. Погіршується кровопостачання м'язів серця, інших органів. Спостерігається погіршення еластичності легеневих тканин, ослаблення дихальних м'язів, що призводить до зменшення легеневої вентиляції. Спостерігається погіршення еластичності м'язів і зв'язок. Зменшення збуджуваності нервово-м'язового апарату і швидкості скорочень м'язів призводять до зменшення величини сили. Уповільнюється перехід м'язів із напруженого стану до розслабленого. Відбувається нерівномірна атрофія м'язів. Краща моторна реакція відмічається для відносно дрібних м'язових груп кисті, передпліччя, стопи і гомілок, гірша - для м'язів тулуба .

При напруженій м'язовій роботі значення хвилинного об'єму дихання та кровообігу, їх частота досягають граничних значень (Самохвалова та ін., 2018).

Арсенал засобів регламентується програмами з ФВ для ЗВО. Добір засобів і методів здійснюється за розсудом викладача з урахуванням фк-с інтересів та інших особливостей тих, хто займається: рівня їхнього здоров'я, фк-освіти, ФП, наявності умов для занять, екологічного добробуту. Базовою програмою забороняється використання засобів і методів, пов'язаних із невиправданим ризиком для життя і здоров'я тих, хто займається, а також таких, які не відповідають етичним вимогам, формують культ насильства і жорстокості (Базова програма з ФВ, для студ.).

Розроблена (Мільнер, 1999) альтернативна методика оздоровчого тренування за допомогою засобів атлетичної гімнастики. Усі вправи, у тому числі й розминочні, проводяться з обтяженням. Переваги надаються трьом вправам: жим штанги лежачи, присідання зі штангою на плечах, тяга штанги вузьким хватом від підлоги до колін - тому що саме ці вправи найбільш повно відповідають можливостям і потребам юнаків. Передбачається багатократне (по 10-20) піднімання штанги порівняно невеликої ваги.

Особлива увага приділяється ритмічному диханню і вправам на розслаблення. Переваги занять із обтяженням перед заняттями бігом, ходьбою чи плаванням полягають у більших можливостях задавати абсолютно точне навантаження. Ефект посилюється при поєднанні розвитку сили з іншими оздоровчими засобами: бігом, нормалізацією харчування, загартуванням.

Заслуговує на увагу організація занять зі студентами підготовчого відділення, яка поєднує роботу над загальною фізичною підготовленістю із заняттями обраним видом спорту. Відвідування студентами старших курсів 
навчальних занять зі спеціалізації дозволяє їм, до моменту завершення навчання в 3ВО, досягти найкращого фізичного стану.

На думку А. Й. Мачіса, близько 70 \% часу основної частини заняття слід приділяти розвиткові фізичних якостей. При цьому біля 70 \% з цього часу необхідно відводити на розвиток витривалості, $30 \%$ - на розвиток інших фізичних якостей, ще 30 \% - навчанню техніці фізичних вправ.

Н. Е. Мананков вважає, що 40 \% заняття зі студентами слід відводити розвиткові сили, $60 \%$ - розвиткові швидкості, витривалості, гнучкості та інших фізичних якостей.

Я. М. Носова вважає доцільним таке співвідношення засобів фізичного виховання на академічних заняттях зі студентами з низьким рівнем фізичної і технічної підготовленості. На заняттях зі студентами 1-2 курсів 70 \% слід відводити загальній фізичній підготовці і 30 \% часу спеціалізації в одному (обраному) виді спорту. На 3-4 курсах обсяг засобів загальної фізичної підготовки зменшується до 37 \% за рахунок зростання (до 63 \%) обсягу засобів одного виду спорту.

Провідними фахівцями (Рибалко та ін., 2017; Самохвалова та ін., 2018; Худолій, 2008) експериментально підтверджено ефективність організації занять на першому курсі комплексного спрямування, яке передбачає розвиток в основній частині заняття не більше трьох фізичних якостей. На другому курсі заняття повинні носити вибіркову спрямованість, при якій близько $80 \%$ часу основної частини відводиться на розвиток однієї фізичної якості, але не довше ніж 4 заняття підряд.

На думку В. І. Козлова, у зв'язку з прогресом негативних результатів дефіциту рухової активності у студентів від курсу до курсу, доцільно поступово збільшувати рухову щільність занять і обсяг навантаження, зі змішаною енергетичною спрямованістю 3 переважним застосуванням елементів ігрових видів спорту, ритмічної гімнастики (у дівчат), циклічних вправ, при 8 годинах занять на тиждень. Установлено, що застосування ігрового методу в 50 \% усіх занять дозволяє зберегти вищий і стійкіший рівень зацікавленості ігровими заняттями ніж в 25, 75, 100 \%. Застосування ігрового методу в 75 \%, i, особливо, у 100 \% занять поступово знижує інтерес до його застосування в усіх розділах програми і веде до так званого ігрового перенасичення (Рибалко, 2016; Самохвалова та ін., 2018). Пропонується з кожним роком збільшувати кількість часу академічного заняття, що проводиться у формі колового тренування. 1 курс - 30 \%, 2 - 45 \%, 3 курс - 60 \%.

По закінченню шкільного курсу з ФВ в молодих людей вже сформований певний арсенал життєво важливих рухових умінь і навичок. 
Серед них є рухові дії, що широко використовуються в життєвій практиці, і такі, що можуть слугувати конструктивними елементами (будівельним матеріалом) при потребі побудувати новий рух. У студентському віці вдосконалення координаційних можливостей уповільнюється. Тому акцент у ФВ студентів ЗВО слід робити на навчанні координаційно простим, прикладним рухам. Необхідним є врахування передумов процесу навчання. Готовність до навчання руховим діям визначається трьома компонентами:

- фізична готовність (стан фізичних якостей, які необхідні для виконання дій);

- руховий досвід (фонд придбаних раніше рухових умінь, навичок, знань);

- психічна готовність (особистісно-психічні чинники, що мобілізують до дії і визначають характер поведінки при їі виконанні).

При навчанні руховим діям у ЗВО не передбачається досягнення максимально високого ступеню досконалості вмінь та навичок. При навчанні низці рухових дій формуються не стільки навички, скільки вміння. Використання підвідних вправ дає можливість сформувати їх лише до стадії початкового вміння. Тому значне місце відводиться навчанню підготовчим, підвідним вправам.

Форми фізичного виховання у ЗВО поділяються на навчальні (академічні і факультативні заняття) та позанавчальні. До позанавчальних форм відносять такі:

- у режимі робочого дня - гімнастика, ФК-паузи, фк-хвилинки, мікропаузи, ввідна гімнастика, корегуюча гімнастика тощо;

- самостійні заняття: групові (у секції, групі ЗФП, Здоров'я тощо);

- індивідуальні (активний відпочинок, заняття під час сесії, канікул, виконання завдань викладача, домашні завдання);

- масові: спортивні розваги, прогулянки, екскурсії, походи, ФК виступи, свято, змагання, спартакіади, табори відпочинку.

Різний рівень знань, здоров'я, фізичної та спортивної підготовленості студентів, багатоплановість їх інтересів передбачають використання на кафедрі ФВ у позанавчальний час різноманітних форм занять фізичними вправами, спортом, туризмом (Козерук та Новопашен, 2014; Самохвалова та iн., 2018).

Фізкульт-паузи покликані попередити втому, покращити функціональний стан для підтримання робочої працездатності. Комплекс складається з 4-6 вправ, що виконуються на робочому місці, виконання триває 5-7 хв. ЧСС зростає до 110-120 уд./хв. посередині комплексу і до кінця його - повертається до вихідного рівня. За 8-годинного робочого дня 
використовується до 5-6 фк-пауз і фк-хвилин, у тому числі через 2-3 години занять і за 2 год до їх закінчення. Для м’язів, що при виконанні роботи знаходилися в статичному положенні (при навчанні це тулуб, ноги, плечі, таз) дається динамічне навантаження. М'язи, що виконували динамічну роботу - підлягають розслабленню. Комплекс фк-хвилинки для студента повинен містити вправи для великих м'язових груп і вправи на розслаблення і гнучкість хребта. Для зменшення тонусу судин головного мозку даються вправи з обертанням голови, скручуванням тулуба.

Пропонується така послідовність вправ:

1. Потягування. 2. Вправи на розслаблення м'язів рук, ніг, тулуба. 3. Для зміцнення м'язів ніг. 4. Для збільшення чи підтримання рухливості хребта. 5. Для збільшення кровообігу і дихання. 6. Для м'язів тулуба. 7. На координацію і увагу.

Фізкульт-хвилинки - своєрідна вкорочена фк-пауза. Комплекс містить 2-3 вправи, виконується кожні 1,5-2 год. Різновид - мікропаузи тривалістю 20-30 с. Коригувальна гімнастика застосовується для профілактики професійних захворювань.

Самостійні форми занять для студентів ПТУ, технікумів, коледжів, інститутів у позанавчальний час є: групові (в секції, групі ЗФП, Здоров'я тощо), та індивідуальні (активний відпочинок, заняття під час сесії, канікул, виконання завдань викладача, домашні завдання). У навчальних групах заняття спрямовані на підвищення рівня всебічної фізичної підготовки, поглиблене відпрацювання технічних прийомів та їх поєднання з обраного виду спорту, вивчення тактичних дій правил змагань здобуття знань і навичок суддівства навичок проведення занять із новачками, досягнення результатів. Спортивні відділення (секції) створюються за видами спорту, які мають найбільше прикладне значення для успішного оволодіння професією, а також з тих видів, для яких $\epsilon$ належні умови. Заняття проводиться 2-3 рази на тиждень (60-90 хв. у ПтУ; 90-120 хв. у технікумах, коледжах та інститутах). Секції з туризму культивуються у значній кількості у закладів вищої освіти. Робота в них складається з таких розділів:

- практичних занять з учнями (студентами) по навчанню прийомам туризму (техніки та тактики);

- підготовка громадського активу з туризму;

- проведення туристських змагань, залікових і тренувальних походів.

До спортивних секцій (спортивних відділень) розподіляють студентів, які виявили бажання вдосконалювати спортивну майстерність в одному 3 видів спорту, що культивуються в закладі освіти. Тут займаються студенти, які 
за даними тестування мають високі показники фізичної підготовленості та виконали вимоги спортивної класифікації (або мають певну перспективу), групи з загальної фізичної підготовки організовуються для студентів, які ще не підготовлені до занять в спортивних секціях та являються своєрідною перехідною формою від занять із загальнопідготовчим спрямуванням до спеціалізованих занять спортом. Вони створюються для студентів, які бажають покращити фізичну підготовленість з метою успішного оволодіння матеріалом навчальної програми, а також тих, які хотіли 6 удосконалюватись у певному виді спорту, але ще не обрали спеціалізацію.

Такі групи комплектуються переважно за статевими або віковими ознаками. Заняття проводиться 2-3 рази на тиждень (45-60 хвилин - у 3ВО 1-2 рівнів акредитації; 80-90 хвилин у 3ВО 3-4 рівнів акредитації).

Основні задачі секцій: залучити до систематичної роботи над підвищенням своєї загальної фізичної підготовленості та сприяти вибору спортивної спеціалізації; покращити фізичну підготовленість і на ї̈ основі сприяти загальному фізичному розвиткові й успішному виконанню вимог навчальної програми. Різний рівень фізичної підготовленості осіб передбачає використання гандикапів і коефіцієнтів при масових формах занять: спортивні розваги, прогулянки, екскурсії, походи, ФК-виступи, свято, змагання, спартакіади.

Спортивні змагання є однією з найбільш ефективних форм організації масової, фізкультурної і спортивної роботи. Студенти, які розпочали тренування з будь-якого виду спорту, за рідким винятком з великою охотою беруть участь у змаганнях. Їх результат - найбільш вірогідний інтегральний показник рівня набутої у процесі тренувань майстерності.

Багатостепеневість внутрішньої системи змагань - на першість навчальної групи, курсу, факультету, факультетів, закладу освіти, кубкові змагання та чемпіонати, дає змогу кожному студенту, залученому до спортивно-масової роботи, виступати 8-10 разів на рік. Цього достатньо, щоб підтримувати особисту мотивацію до занять.

Практика показує, що студенти, які займаються в секції, виступають у змаганнях і з інших видів спорту. У свій час така багатоборна підготовка заохочувалася кафедрами ФВ ЗВО. Таким чином, фізкультурно-спортивні заходи, окрім виявлення бажаючих займатися в секціях з видів спорту, надають можливість оцінити свої досягнення, сприяють підготовці до складання нормативів і разом із тим дають змогу виявити найбільш здібних для комплектування команд для участі в змаганнях вищого рівня. 
Традиційно головне місце серед змагань у зВО займає спартакіада. Положення про комплексну спартакіаду розробляється кафедрою ФВ і спортивним клубом з урахуванням наявної матеріальної бази, наявності спеціалістів з видів спорту, фізкультурного активу тощо. Положення узгоджується зі студентським профкомом і затверджується ректоратом 3 ВО.

Головним при складанні положення $є$ збереження інтересів спортивних колективів і окремих спортсменів, забезпечення рівних умов для всіх їі учасників. Не менш важливими $\epsilon$ агітаційно-пропагандистські заходи під час проведення й підготовки спартакіади. Ретельна підготовка учасників і місць змагань, урочисте відкриття змагань і підведення їх підсумків, своєчасне висвітлення їі результатів у таблицях, стіннівці - все це підвищує інтерес до змагань, сприяє залученню студентів у спортивні осередки.

Організація та проведення фрізкультурно-оздоровчої та спортивної роботи в місиях масового відпочинку студентів.

Види таборів: оздоровчі табори; оздоровчо-спортивні табори; спортивні табори; табори відпочинку та праці; туристичні табори; військові табори. У свою чергу, ці табори підрозділяються на дві групи (в залежності від сезону - літні, зимові).

Загальні задачі ФВ студентської молоді в таборах відпочинку: 1) зміцнення здоров'я відпочиваючих засобами ФК і спорту з урахуванням природних кліматичних умов і на цій основі підвищення рівня всебічної фізичної підготовки й загальної працездатності організму; 2) залучення до регулярних занять ФК і спортом студентів; 3) підготовка громадських інструкторів та суддів по спорту; 4) ознайомлення із санітарно-гігієнічними вимогами користування природними засобами; 5) прищеплення навичок дотримання розумного та раціонального режиму відпочинку; 6) виховання навичок самоуправління та організації активного відпочинку; 7) виховання студентської молоді в дусі патріотизму, високої моралі й колективізму.

Задачі можуть конкретизуватися в залежності від типу табору. Сувора диференціація процесу фізичного виховання, з урахуванням рівня фізичної підготовленості, правильний розподіл видів занять протягом дня, захоплюючі фізкультурно-масові і спортивні заходи - основні принципи навчально-тренувального процесу в таборі. У таборах можуть бути застосовані такі форми навчально-спортивної та масовооздоровчої роботи:

1. Щоденна ранкова гігієнічна гімнастика. Проводять усім складом студентів, які відпочивають у таборі. Поділ на групи для виконання РГГ не рекомендується. Комплекси складаються таким чином, щоб кожні 5 днів зростало навантаження. 2. Навчально-тренувальні занятя проводяться 
ввечері (зранку). Для занять і участі в змаганнях відводиться 2,5-5 години щодня. 3. Заняття з плавання. 4. Заняття зі студентами з відхиленням у стані здоров'я. 5. Заняття на пляжі з метою збільшення обсягу рухової активності тривають до 2 годин щодня. 6. Загартовування повітрям, сонцем, водою. 7. Туристичні походи (одно- і багатоденні). Навчання встановлювати палатки, вкладати заплічник, розкладати багаття, в'язати вузли, застосовувати страхування, вести групу, регулювати швидкість ходьби, здійснювати переправу. 8. Змагання з різних видів спорту. Змагання мають найбільший ефект, коли вони: проводяться за традиційною, відомою всім програмою, підводять підсумок роботи за сезон, забезпечені відповідним суддівством і санітарним обслуговуванням, залучають до участі всіх студентів, використовують популярні види спорту. 9. Трудові процеси (прибирання території тощо). 10. Інструкторсько-методичні заняття. Рекомендується для правильної організації навчально-виховної роботи в умовах спортивного табору:

- побудова і проведення процесу ФВ відповідно до віку, стану здоров'я, загальної фізичної підготовленості тощо;

- забезпечення однорідності груп з урахуванням статі, віку, підготовленості, схильностей до певного виду спорту;

- розробка плану спортивно-масової фізичної підготовки з урахуванням специфіки місця й часу відпочинку, специфіки табору;

- систематичне проведення різних змагань між різними групами студентів;

- використання різноманітного інвентарю;

- лікарсько-педагогічний контроль.

Висновки. Аналізуючи дані, можна стверджувати, що для підвищення ефективності академічних занять з фізичного виховання у ЗВО необхідно збільшити обсяг вправ, що виконуються в II зоні потужності, зменшивши, при цьому, обсяг малоінтенсивних засобів.

Більш пильної уваги заслуговує проблема створення ефективного комплексу педагогічних умов адаптивного фізичного виховання студентів $з$ ослабленим здоров'ям, що пов'язано з вирішенням протиріччя між звільненням студентів від занять з фізичного виховання і зміцненням здоров'я засобами фізичної культури.

\section{ЛІТЕРАТУРА}

Закон України «Про фрізичну культуру $і$ спорт». Режим доступу: https://zakon.help/law/3808-XII/ (Law of Ukraine "On Physical Culture and Sport". Retrieved from: https://zakon.help/law/3808-XII/).

Козерук, Ю. В., Новопашен, С. С. (2014). Організаційно-методичні і практичні рекомендації проведення позаурочних оздоровчих занять фізичними вправами. Наука і освіma, 4, 85-88 (Kosuruk, Yu. V., Novopashen, S. S. (2014). Organizational- 
methodological and practical recommendations for carrying out extra-curricular classes with physical exercises. Science and Education, 4, 85-88).

Куртова, Г., Рибалко, П., Красілов, А. (2018). Педагогічні умови формування здоров'язбережувальної компетентності фахівців аграрного сектору у процесі фізичного виховання. Педагогічні науки: теорія, історія, інноваційні технології, 4, 100-111 (Kurtova, H., Rybalko, P., Krasilov, A. (2018). Pedagogical conditions of formation of health-saving competence of the agrarian sector specialists in the process of physical education. Pedagogical sciences: theory, history, innovative technologies, 4, 100-111).

Рибалко, П. Ф. (2016). Сучасні технології збереження та відновлення здоров'я молоді в діяльності фахівця з фізичної культури. Вісник Чернігівського національного педагогічного університету імені Т. Г. Шевченко, 136. Серія: Педагогічні науки, 181-184 (Rybalko, P. F. (2016). Modern technologies for the preservation and restoration of young people's health in the activity of a specialist in physical culture. Bulletin of Taras Shevchenko Chernigiv National Pedagogical University, 136. Series: Pedagogical Sciences, 181-184).

Рибалко, П. Ф., Гриб, Т. О., Клименченко, Т. Г. (2017). Проблеми і шляхи підвищення ефективності фізичного виховання у вищому навчальному закладі нефізкультурного профілю. Фізична культура, спорт та здоров'я нації, 1, 217221 (Rybalko, P. F., Hryb, T. O., Klymenchenko, T. H. (2017). Problems and ways to improve the efficiency of physical education in higher education institutions of nonphysical education profile. Physical Culture, Sport and Health of the Nation, 1, 217221).

Рибалко, П. Ф., Козерук, Ю. В., Лисюк, С. М., Гончар, В. В. (2016). Теоретико-методичні основи організації самостійних занять фізичними вправами. Вісник Чернігівського національного педагогічного університету імені Т. Г. Шевченко. Серія: Педагогічні науки, 213-216 (Rybalko, P. F., Koseruk, Yu. V., Lysiuk, S. M., Honchar, V. V. (2016). Theoretical and methodological foundations of organization of independent classes with physical exercises. Bulletin of Taras Shevchenko Chernigiv National Pedagogical University. Series: Pedagogical Sciences, 213-216).

Рибалко, П., Хоменко, С. (2018). Формування комплексної системи розвитку силових здібностей студентів аграрного вузу на заняттях з тхеквондо. Фізична культура $i$ cпopm, 5 (24), 107-113 (Rybalko, P., Khomenko, S. (2018). Formation of the complex system of development of power abilities of agrarian higher school students at classes in taekwondo. Physical Culture and Sport, 5 (24), 107-113).

Самохвалова, І. Ю., Мелюшкина, В. В., Рибалко, П. Ф. (2018). Настільний теніс як засіб розвитку координаційних здібностей студентів аграрного університету. Вісник Чернігівського національного педагогічного університету. Серія: Педагогічні науки, 151(1), 133-136 (Samokhvalova, I. Yu., Meliushkina, V. V., Rybalko, P. F. (2018). Table tennis as a means of developing coordination abilities of students of the agrarian university. Bulletin of Chernihiv National Pedagogical University. Series: Pedagogical Sciences, 151 (1), 133-136).

Худолій, О. М. (2008). Загальні основи теорії і методики фізичного виховання. Харків: OBC (Khudolii, O. M. (2008). General principles of the theory and method of physical education. Kharkiv: ATS). 


\section{PEЗЮME}

Харченко Роман, Хоменко Сергей, Красилов Андрей, Рыбалко Петр. Методика преподавания учебной дисциплины «Физическое воспитание» в высшем учебном заведении.

Содержание данной статьи заключается в создании и апробации методики, которая позволяет учитывать особенности студентов в зависимости от объема специальной двигательной активности и успешности обучения, существенно повышая производительность их двигательных умений и познавательной активности. Рассмотрено состояние высшего образования на современном этапе развития общества. Во-первых, на фоне общих изменений, которые происходят с высшим образованием, a, во-вторых, с учетом особенностей программного содержания обучения студентов высшего учебного заведения и контингента студентов.

Ключевые слова: студент, физическое воспитание, обучение, высшее учебное заведение, здоровье, физические качества.

\section{SUMMARY}

Kharchenko Roman, Khomenko Serhii, Krasilov Andrii, Rybalko Petro. Methodology of teaching discipline "physical education" in a higher education institution.

In connection with expansion of the market of educational services and emergence of new specializations, students who differ from the majority by the small volume of motor activity, arose the question about the study of an optimal system of educational activities that takes into account the features of different groups of students.

Nowadays acute remains a problem of increasing cognitive activity of students, which finds its solution in the development of active teaching methods and creation of new forms of organization of the educational process. Development of new pedagogical approaches in education is largely connected with the concept of personality-oriented pedagogy, which should be reflected in the education system.

In this regard, in practice, the reserves of individualization of the educational process should be used more widely. At the same time, there is no coherent mechanism for the formation of flexible models of the education system, which take into account not only the requirements for the future profession, but also the individual characteristics of students. Formation of the optimal system of training activities in physical education becomes especially relevant in connection with adaptation of the program content to teaching students new specialties and specializations. The main tasks of work with student youth are: involving in systematic work on increasing general physical preparedness and promoting the choice of sports specialization; improving physical fitness and, on the basis of it, contributing to the overall physical development and successful fulfillment of the requirements of the curriculum.

In the conditions of higher education institutions sports competitions and sports events are a means of attracting students to classes, increasing their physical and functional readiness, and developing useful motor skills. Their availability for students is conditioned by a properly organized internal calendar of sporting events, selection of competitive exercises and opportunities for participation of students with different levels of physical fitness at the expense of handicaps, coefficients.

Key words: student, physical education, education, higher education institution, health, physical qualities. 